Розділ 4. Журналістика та засоби масової інформації

Part 4. Journalism and Mass Communication

https://doi.org/10.31516/2410-5333.056.17

UDC 316.776

O. I. Romanyuk, Doctor in Political Sciences, Professor, Kharkiv State Academy of Culture, Kharkiv

olexromanyuk@ukr.net

https:orcid.org/0000-0002-8756-9018

I. P. Kovalenko, Candidate of Sciences in Social Communication, Associate

Professor, Kharkiv State Academy of Culture, Kharkiv

irinapavlovna236@gmail.com

https://orcid.org/0000-0001-6205-263X

\title{
SOCIAL RESPONSIBILITY OF THE MASS-MEDIA: AN ATTEMPT AT CONCEPTUAL JUSTIFICATION ${ }^{1}$
}

The aim of this paper contains to conceptualize understand the phenomenon of social responsibility of the mass-media. Social responsibility of the media is interpreted as their responsibility to society for their actions and their consequences. According to the two main ways of regulating social relations, the authors distinguish two main types of social responsibility of the media - legal and moral, and material responsibility is treated as a derivative phenomenon. The reasons of distortions in the objectivity of media information are analyzed at the social and personal levels. The article proposes ways to enhance social responsibility of mass-media. The authors conclude that moral factors play a much greater role than the legal ones in enhancing media social responsibility.

Keywords: mass-media, social communication, social responsibility, journalism, media law, media culture.

А. И. Романюк, доктор политических наук, профессор, Харьковская государственная академия культуры, г. Харьков

И. П. Коваленко, кандидат наук по социальным коммуникациям, доцент, Харьковская государственная академия культуры, г. Харьков

\section{СОЦИАЛЬНАЯ ОТВЕТСТВЕННОСТЬ СРЕДСТВ МАССОВОЙ ИНФОРМАЦИИ: ПОПЫТКА КОНЦЕПТУАЛЬНОГО ОБОСНОВАНИЯ}

В статье делается попытка концептуального осмысления феномена социальной ответственности средств массовой информации. В соответствии с двумя основными способами регулирования общественных отношений авторы выделяют два основных типа социальной ответственности СМИ правовой и нравственный, а материальная ответственность трактуется как производное от них явление. На социальном и персональном уровнях

1 This work is licensed under a Creative Commons Attribution-NonCommercialShareAlike 4.0 International License. 
анализируются причины искажения объективности медиаинформации. Предлагаются пути усиления социальной ответственности СМИ. Сделан вывод, согласно которому для усиления социальной ответственности СМИ моральные факторы имеют большее значение, чем правовые.

Ключевые слова: средства массовой информации, социальная коммуникация, социальная ответственность, журналистика, медиаправо, медиакультура.

О. І. Романюк, доктор політичних наук, професор, Харківська державна академія культури, Харків

І. П. Коваленко, кандидат наук із соціальних комунікацій, доцент, Харківська державна академія культури, м. Харків

\section{СОЦІАЛЬНА ВІДПОВІДАЛЬНІСТЬ ЗАСОБІВ МАСОВОЇ ІНФОРМАЦІї: СПРОБА КОНЦЕПТУАЛЬНОГО ОБҐРУНТУВАННЯ}

Актуальність. Технічна революція в інформаційному просторі мала деякі негативні наслідки, оскільки виникло більше можливостей для маніпуляції поведінкою громадян. Цим часто користуються недоброчесні політики, недемократичні сили як усередині країни, так і закордонні, що нині створює значні проблеми навіть для сталих ліберальних демократій. У такій ситуації великої актуальності набуває проблема соціальної відповідальності засобів масової інформації за наслідки інформаційної діяльності.

Мета статті полягає в спробі концептуального осмислення поняття соціальної відповідальності стосовно діяльності засобів масової інформації.

Методологія розвідки ґрунтується на структурно-функціональному аналізі феномену соціальної відповідальності ЗМІ.

Результати. Соціальна відповідальність ЗМІ трактується як їхня відповідальність перед суспільством за свої дії та їхні наслідки. Відповідно до двох основних способів регулювання соціальних відносин вирізняємо два основні типи соціальної відповідальності ЗМІ - правовий та моральний, а матеріальна відповідальність трактується як похідне від них явище. На соціальному та персональному рівнях аналізуються причини спотворення об'єктивності медійної інформації. Пропонуються шляхи посилення соціальної відповідальності ЗМІ. Висновано, що в посиленні соціальної відповідальності ЗМІ моральні чинники відіграють значно більшу роль, ніж правові.

Новизна. Уперше проблема соціальної відповідальності ЗМІ досліджується в контексті не лише правового, але й морального способу регулювання суспільних відносин.

Практичне значення. Матеріали і висновки дослідження можуть використовуватися в практичній діяльності з удосконалення функціонування медіасередовища, а також для фахової підготовки журналістських кадрів.

Ключові слова: засоби масової інформації, соціальна комунікація, соціальна відповідальність, журналістика, медійне право, медійна культура.

Problem statement. One of the key trends in the development of the modern world is the increasing influence of the media and social communication on the formation of consciousness and behavior of citizens, caused by the rapid development of information technologies In the first 
half of the 20th century newspapers were the main technical means of disseminating media, in the second half of the 20th century television became the main medium, but in early 21 st century this role drifted to the Internet. Thanks to new technical devices such as laptops and smartphones, the citizens have been able to stay in the information space all the time.

However, the technological revolution in the information space has brought about negative consequences as the possibilities of manipulating citizens' behavior have increased significantly. Unscrupulous politicians, undemocratic forces both in Ukraine and internationally pose great problems today even for stable liberal democracies. In such a situation, the problem of social responsibility of the mass-media (their owners, editors, journalists) for the consequences of information activity becomes more relevant.

Previous research. Various aspects of the issue of social responsibility in the media were discussed in publications by Harold Lasswell with Abraham Kaplan (1950), Denis McQuail (1987), Judith Lichtenberg (1991), Marion Dönhoff (1997), Andrea Hunter (2015), and Ukrainian researchers as Kateryna Nazarenko (2016), Zoriana Haladzhun (2017), Yaroslav Teleshun (2017), Iryna Kovalenko (2018 and 2019). However, a holistic conceptual understanding of the phenomenon of social responsibility relating to media activities has not yet been formed.

Accordingly, the aim of this paper is to make an attempt at conceptualizing the social responsibility in relation to media activities.

What is Social Responsibility. The phrase «social responsibility» literally means a responsibility to the society (society). That is, the subjects of social relations should be held accountable to society for their actions and their consequences. As Kateryna Nazarenko points out: "We understand social responsibility as a duty to perform socially accepted norms of action that contribute to the public well-beigng, characterized by the formation of a responsible attitude in the implementation of relations between any social entity and society" (Nazarenko 2016).

Since there are two main ways of regulating - legal and moral social relations, two relevant types of social responsibility should be distinguished. A legal responsibility is the responsibility of social relations actors for their actions with the Law. It provides for punitive sanctions for violations of applicable legal norms. Legal responsibility is ensured by the state's law institutions. Moral responsibility is the responsibility of the subjects of social relations for their actions from the standpoint of social morality. Unlike legal responsibility, moral responsibility does not imply any punitive sanctions on the state, but only condemnation of certain actions by citizens and public structures. Legal and moral responsibility can be the identical when certain actions entail not only criminal sanctions on the part of law 
enforcement agencies but also cause public condemnation. However, this does not always happen. The nonconformity may be due to the nature of the political regime, because the punitive sanctions for violations of existing laws do not always meet with public support under undemocratic rule. But even in democracies, not all actions that cause negative social consequences are subject to the Law.

Social responsibility in the media space. Social responsibility extends to all spheres of public life, but each has its own peculiarities. An interesting definition of the essence of social responsibility in the media sphere is offered by Zoryana Haladzhun who points out that in their activities the mass media "must fulfill certain obligations to the society", which "provides for publication of materials that meet high professional standards of information, accuracy, activity and balance" (Haladzhun 2017: 70). The specific features of social responsibility in the media space is due to the facts that:

Firstly, its subject matter is information disseminated by the media;

Secondly, the legal entities with responsibility are the media, the individuals is their owners, editors and journalists;

Thirdly, the user of the mass media production is the whole society;

Fourthly, the relationship between the mass-media and society is governed by a special branch of a information law - a media law.

In content, a media law is a set of legal rules governing the functioning of mass-media and their connections with the social environment in a particular country. The generally accepted norms of the modern states' media law are requirements for information objectivity, impartiality, reliability and completeness. As an example, according to Article 2 of the Law of Ukraine "On Information", one of the basic principles of information relations is "reliability and completeness of information" (Law 1992a). The 26th article of the Law of Ukraine (1992) "On printed mass media (press) in Ukraine" requires journalists to "submit for publication objective and reliable information" (Law 1992b). The 59th article of the Law of Ukraine "On Television and Radio Broadcasting in Ukraine" assigns the responsibilities of broadcasters to "disseminate objective information" (Law 1993). The 3rd article of the Law of Ukraine (2014) "On Public Television and Radio Broadcasting of Ukraine" emphasizes that the important principle of the National Public Broadcasting Company of Ukraine is "comprehensive, objective and balanced informing about socially significant events in Ukraine and abroad" (Law 2014). However, there are very few effective controls for the accuracy and, moreover, completeness of information. In the legal plane, the reliability of information can be established by a court if it is addressed by the victims of such information and only if there are incontrovertible facts about the unreliability. The adjudication of incompleteness of information is 
a much more difficult matter, almost in vain. A judgment on incompleteness of information can be made only if the incompleteness causes great harm to a certain subject of social relations and it must be legally proved.

An important means of controlling the reliability and completeness of information is monitoring media activities carried out by public organizations. However, the monitoring results rarely influence court decisions. They are much more effective in influencing public opinion on particular media, causing to form their positive or negative image. In this case, responsibility comes on the moral plane, but it is also reflected in material relationships.

Thus, we reach the second level of social responsibility of the media. We define it as a second one because material responsibility is mediated by legal decisions and/or moral condemnation in one way or another (figure1).

1st level

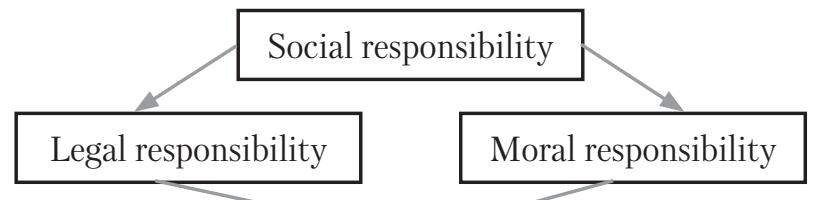

2nd level

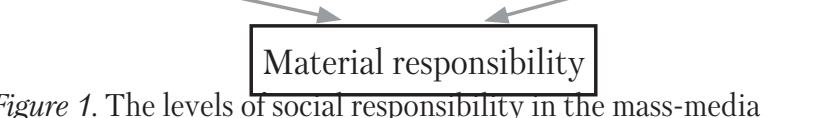

The material (property, monetary) losses can be incurred by the media, their owners and functionaries as a result of court decisions (fines or, even, closure of the media) or by citizens' refusal to "buy" their information products.

A specific type of responsibility in the media sphere is political responsibility, by which we mean the responsibility of the media for the political consequences of their information products. Unfair, distorted and engaging medial information can lead to governmental power being obtained by undemocratic politicians, which threatens the democratic development of society. It must be remembered that Hitler, in due course, came to power through democratic procedures. In the 1932 elections to the Reichstag, the National Socialist Party received a large majority of votes, thanks in large part to the mass agitation carried out not only by the Nazi but also by conservative publications. In our view, political responsibility is a kind of moral responsibility. It does not impose any punitive sanctions, but only moral condemnation. In this context, the specificity of the political responsibility of the mass-media is that they are transformed into a puppet of the regime, the journalists are deprived of the freedom of their professional activity, and the society are deprived of the freedom of speech (Romanyuk\& Kovalenko 2017: 247-249). 
Why the honesty of information is violated. Apart from the pressure on the media by a bad government, which has already been discussed, there are other reasons for the deformation of media information. The social responsibility of the mass-media acts not only in a collective form but also in an individual one, as the personal responsibility of their owners, editors and journalists. Each of these participants in the process of production and dissemination of information has its own interests that may not match with, or even contradict with, the social ones. The conflict between social and personal interests cannot but affect the quality of media information, leading to violations of the principles of its reliability and completeness.

The owners are often big business representatives who put pressure on their media to get citizens to support laws and government decisions that are beneficial to their businesses or to please the government. In many cases, they are affiliated with political parties (usually the right wing), which also affects the political preferences of their mass-media.

The editors who officially define a policy of mass-media depend on the owners, both financially and by their own posts. The conflicts between owners and editors that occasionally arise in the media space often result in the termination of contracts and the dismissal of editors. However, the support of the editor by the staff and its readiness for protest actions (such as a strike) make it impossible for such intentions of the owner in some cases.

The journalists are those participants in media production who are directly involved in the collection, analysis and interpretation of information. When preparing their information product, they frequently get pressured by editors who force them to adhere to the publication's policies or/and carry outfulfill orders of the media owner. However, the reason for the misrepresentation of the information by journalists may be some order from a «third-party». Another reason for the dissemination of false information by journalists may be their incompetence in the field they cover in their publications or their general unprofessionalism. As Andrea Hunter puts it: "Journalism is a profession that is different from occupations such as medicine or law, in that there is no set exam that must be passed, or strict professional guidelines that must be followed, neither is there a requirement for formal education" (Hunter 2015: 275).

Ways to strengthen social responsibility. Undoubtedly, the main way of strengthening social responsibility of mass-media is the democratization of public relations, ensuring freedom of speech in full and eliminating cases of government pressure on them. Yaroslav Teleshun points out that "in 'developed democracies' media involvement in socio-political and economic processes is limited by a sufficiently effective legislative background, stable functioning of the institutional environment, socio-political culture and 


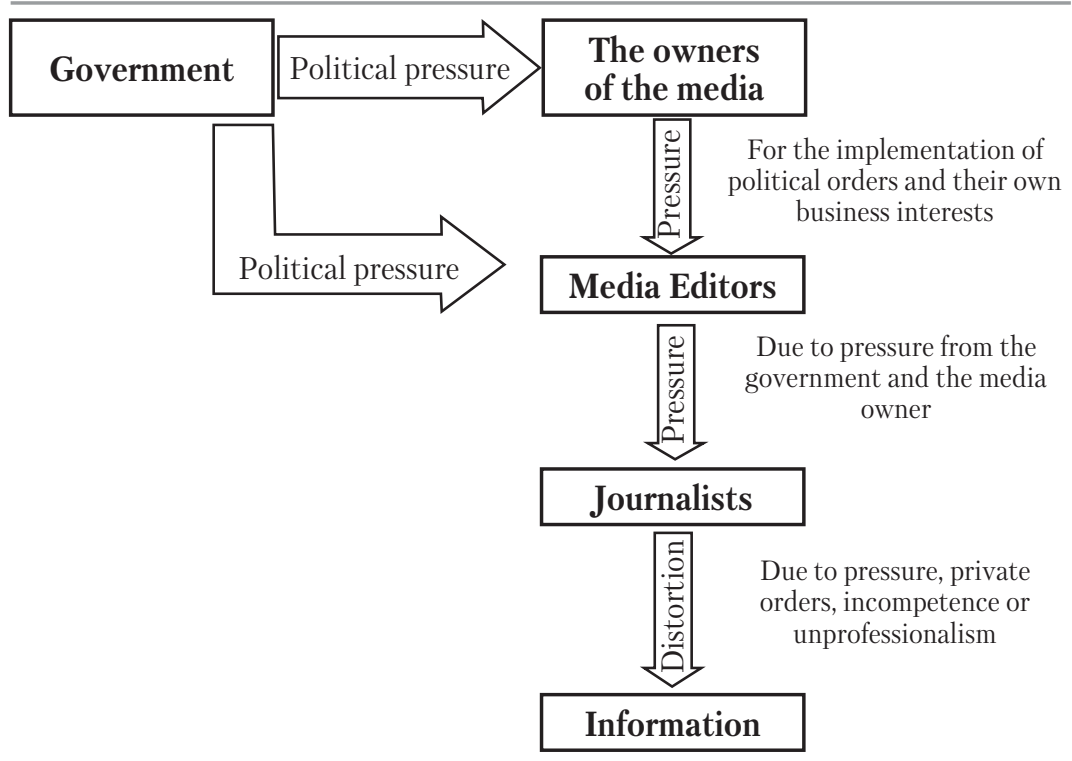

Figure 2. Mechanism of media information distortion.

traditions, etc." (Teleshun 2017: 58). In one of her previous publications, one of the authors of this article emphasizes: "Although there is not and cannot be any absolute objectivity of the media, the more so in the electoral race, the pluralistic nature of democratic regimes leads to the phenomenon of relative objectivity, which is that voters can use different editions that take different sides and explicitly or implicitly support various political forces and different candidates, compare their publications and then make their own choices" (Kovalenko, 2019: 106).

The second way is to reduce the impact on the media activity from big business, especially oligarchic clans. It is worth agreeing that this will be facilitated by "the creation of an effective legal framework governing the activities of the media resource and its ownership structure" (Teleshun: 62).

The third way is the development of the self-organization of the journalism workshop, the activation of the activities of journalist associations, the creation of trade unions in the media that are able to effectively defend their rights to freedom of professional activity and resist pressure from the authorities and big business.

The fourth is to strengthen the ethical education of journalists, to form in them moral safeguards for the dissemination of untrue information.

The fifth is the improvement of the professional training of journalists, who must not only have a thorough knowledge of the technique of collecting, 
processing and presenting material, but also have a wide range of social knowledge.

Conclusion. Thus, our contribution to the conceptual understanding of the phenomenon of social responsibility in the media space is as follows:

1. Defining the social responsibility of the mass-media as their responsibility for their actions and their consequences in front of society.

2. Identifying two main types of media social responsibility - legal and moral.

3. Regarding the material liability of media as a phenomenon derived from legal and moral responsibility.

4. Identifying the reasons for social and personal display objectivity.

5. Outlining the ways to strengthening social responsibility of the media.

Finally, it should be stressed that in enhancing social responsibility of the media, moral factors play a much greater role than the legal ones. Therefore, the problem of moral regulation of media relations is a promising issue for further research.

\section{References}

Dönhoff, M. G. (1997). Zivilisiert den Kapitalismus: Grenzen der Freiheit. Stuttgart: Deutsche Verlags-Anstalt [in German].

Haladzhun, Z. V. (2017). On the Concept and Types of Social Responsibility in Mass Media. TV and Radio Journalism. Issue 16, 68-74. [in Ukrainian].

Hunter, A. (2015). Crowdfunding Independent and Freelance Journalism: Negotiating Journalistic Norms of Autonomy and Objectivity. New Media \& Society, vol. 17, No. 2, 272-288. [in English]

Kovalenko, I. P. (2019). Journalistic Objectivity in the Process of Political Elections in the Conditions of Democracy. Visnyk of Kharkiv State Academy of Culture, Series: Social Communications, Issue 54, pp. 101-107. [in English].

Kovalenko, I. P. (2018). Problem of Informational Objectivity in the Contex of Journalists' Legal Culture. Visnyk of Kharkiv State Academy of Culture, Series: Social Communications, Issue 53, 169-176. [in English].

Lasswell, H. D. \& A. Kaplan (1950). Power and Society: a Framework for Political Inquiry. New Haven: Yale University Press, pp. XXIV, 295. [In English].

Law of Ukraine (1992a) «On Information». Retrieved from https://zakon.rada. gov.ua/cgi-bin/laws/main.cgi?nreg=2657-12\&p=1217856518710949 [in Ukrainian]

Law of Ukraine (1992b) «On printed mass media (press) in Ukraine». Retrieved from http://zakon2.rada.gov.ua/laws/show/2782-12 [in Ukrainian].

Law of Ukraine (2014) «On Public Television and Radio Broadcasting of Ukraine» Retrieved from https://suspilne.media/documents/1 [in Ukrainian].

Law of Ukraine (1993) «On Television and Radio Broadcasting». Retrieved from http://zakon3.rada.gov.ua/laws/show/3759-12/print1509554453956466 [in Ukrainian]. 
Lichtenberg, J. (1991). In Defense of Objectivity. In J. Curran and M. Gurevitch (Eds.) "Mass Media and Society". 225-242. London: Arnold. [In English].

McQuail, D. (1987). Mass Communication Theory: An Introduction. Beverly Hills, 273 p. [In English].

Nazarenko, C. S. (2016) Social Responsibility of Ukrainian Media as a Subject of Sociological Analysis. Hrani, No. 8 (136), 155-159. [in Ukrainian].

Romanyuk, O\&I. Kovalenko. (2017). The Mass-Media and Political Regimes (The Problem of Mass-Media Determination by Political Regimes). Visnyk of Kharkiv State Academy of Culture, Series: Social Communications, Issue 50, pp. 245-251. [In English].

Teleshun, Ya. (2017). Mass Media As an Instrument of Struggle of Financial-Political Groups: Realities of Ukraine. Scientific Journal of National Pedagogical Drahomanov University, Series 22: Political Science and Methods of Teaching Social and Political Disciplines, issue 22. 57-64. [in Ukrainian].

Надійшла до редколегії 29.11.2019 p. 